\title{
Microbial community composition of black band disease on the coral host Siderastrea siderea from three regions of the wider Caribbean
}

\author{
Raju Sekar*, Longin T. Kaczmarsky, Laurie L. Richardson \\ Department of Biological Sciences, Florida International University, Miami, Florida 33199, USA
}

\begin{abstract}
Microbial communities associated with black band disease (BBD) on colonies of the reef building coral Siderastrea siderea from reefs in 3 regions of the wider Caribbean were studied using 16S rRNA gene-targeted amplification, cloning, and sequencing. Samples were collected from 7 BBD-infected S. siderea colonies on 2 reefs near Lee Stocking Island, Bahamas, one reef in the Florida Keys, Florida, USA, and 2 reefs in St. Croix, US Virgin Islands. Genomic DNA extracted from BBD samples was PCR-amplified with universal bacterial primers (27F and 1492R). Seven clone libraries were constructed and 411 sequences were retrieved. All of the clone libraries were dominated by Alphaproteobacteria and contained sequences associated with bacteria of the sulfur cycle, including the first report of the molecular detection of sequences related to the sulfide-oxidizing genus Beggiatoa in BBD field samples. Additionally, all clone libraries had sequence types of bacteria associated with toxin producing dinoflagellates. These sequences were most abundant in a sewage impacted reef site in St. Croix, which also had the highest prevalence of BBD-infected colonies. Non-metric multidimensional scaling and cluster analysis showed clustering of BBD microbial communities by relative level of anthropogenic impact. The results support the hypothesis that $\mathrm{BBD}$ is composed of variable members of distinct physiological and toxin associated bacterial groups and that the microbial community variation is associated with environmental differences such as anthropogenic impact. We propose that with degrading water quality (i.e. increasing nutrients) certain proteobacteria thrive and increase BBD virulence.
\end{abstract}

KEY WORDS: Black band disease - Coral disease - Siderastrea siderea - Microbial communities · Anthropogenic impact · Caribbean

\section{INTRODUCTION}

Coral diseases are considered to be increasingly important factors in the decline of coral reefs worldwide (Harvell et al. 1999) and appear to be particularly detrimental on reefs of the wider Caribbean (Green \& Bruckner 2000). Thus far, 22 (76\%) of the 29 recognized coral diseases are reported to occur on Caribbean reefs (Sutherland et al. 2004). Of these, black band disease (BBD) is one of the most important, affecting both scleractinian and gorgonian corals (Green \& Bruckner 2000, Sutherland et al. 2004, Weil 2004).
BBD, first reported in the 1970s (Antonius 1973), is characterized by a dark, migrating band which moves across a living coral colony completely lysing coral tissue and often killing the entire colony in a matter of months (Antonius 1981). It is most accurately described as a horizontally migrating, cyanobacterial-dominated, sulfide-rich microbial mat (Carlton \& Richardson 1995) but is unique in that it is pathogenic to corals and is motile. Thus far, in addition to the dominant cyanobacteria, sulfate-reducing bacteria (in particular Desulfovibrio spp.), sulfide-oxidizing bacteria, numerous heterotrophic bacteria, and fungi have been reported in the BBD community (Ducklow \& Mitchell 1979, 
Ramos-Flores 1983, Rützler \& Santavy 1983, Richardson 1996, Cooney et al. 2002, Frias-Lopez et al. 2004, Sekar et al. 2006, Barneah et al. 2007). Members of all of these groups have been proposed as primary pathogens; however, few have been isolated into culture and Koch's postulates have not been fulfilled for any of them (Richardson 2004).

The fulfillment of Koch's postulates has classically been the 'gold standard' for verifying that a suspected microbial pathogen is responsible for a specific disease. To fulfill Koch's postulates requires that the following are conclusively demonstrated: (1) the suspected causal organism must be constantly associated with the diseased host and is not present in healthy hosts; (2) the suspected organism must be cultivated into pure culture from the diseased host; (3) when a healthy host is inoculated with a pure culture of the suspected organism, it should cause the disease; and (4) the organism must be reisolated from the diseased host (Koch 1884). For coral hosts, only bacterial bleaching, sea fan aspergillosis, white plague Type II and white pox have had pathogens isolated and confirmed using Koch's postulates (Sutherland et al. 2004). BBD has been proposed to be a polymicrobial disease (Richardson 2004); therefore, fulfillment of Koch's postulates using a single microorganism may not be applicable. As such, determination of the etiology of this disease will require studies of the BBD microbial community (MC), including identification of key members and their associated pathogenic mechanisms and interactions.

The BBD community is complex and appears to be highly variable. Early studies using microscopic techniques suggested that BBD is a characteristic community dominated by filamentous cyanobacteria and sulfide-oxidizing bacteria (Mitchell \& Chet 1975, Ducklow \& Mitchell 1979, Rützler et al. 1983). More recent cultivation independent (molecular) studies suggest a very high degree of complexity (Cooney et al. 2002, Frias-Lopez et al. 2002, 2003, 2004, Sekar et al. 2006). These studies, most of which included PCR, cloning, and sequencing of the 16S rRNA gene, revealed a diverse assortment of primarily heterotrophic bacteria dominated by Alphaproteobacteria and containing additional different major bacterial groups. The bacterial composition of BBD clone libraries is variable when comparing results of different research groups (Cooney et al. 2002, Frias-Lopez et al. 2002, 2004, Sekar et al. 2006), and even within the same group (Frias-Lopez et al. 2002, 2004).

A high degree of variability may be a characteristic of BBD since this result was also found using 2 different molecular community profiling approaches, terminal restriction fragment length polymorphism (Cooney et al. 2002) and amplicon length heterogeneity of hypervariable regions within the 16S rRNA gene (Sekar et al. 2006, Voss et al. 2007). It is not yet known whether, within the complex BBD community, there are required specific pathogenic species for the disease or whether varying members within 4 proposed physiological functional groups (photoautotrophs, sulfate-reducers, sulfide-oxidizers, and heterotrophs) can cause the disease (Richardson 2004). To date the microbial communities of BBD from only 5 of the 25 species of Caribbean corals and 2 of the 45 species of Indo-Pacific corals known to be susceptible to BBD have been studied using molecular techniques. These are the Caribbean coral hosts Colpophyllia natans (Cooney et al. 2002), Diploria strigosa (Cooney et al. 2002, Frias-Lopez et al. 2004), Montastraea annularis (Cooney et al. 2002, Frias-Lopez et al. 2004), M. cavernosa (Cooney et al. 2002) and Siderastrea siderea (Sekar et al. 2006) and the Indo-Pacific hosts Favia and Favites spp. (Barneah et al. 2007). If there are specific pathogens involved, it will most likely require a larger database with more host species investigated to detect BBD microorganisms common to all infections. This is complicated by that fact that one cannot be assured of obtaining all sequences present in a sample in a clone library. However, since it is well known that $<1 \%$ of microorganisms are typically cultured from environmental samples (Amann et al. 1995), it remains necessary to rely on use of molecular techniques (Rappe \& Giovannoni 2003).

Field observations have indicated that several coral host species and localities are more prone to BBD than others. While it is possible that specific environmental factors are driving these differences, for example sewage input (Kaczmarsky et al. 2005), higher water temperatures (Voss \& Richardson 2006a), and elevated nutrients (Kuta \& Richardson 2002, Voss \& Richardson $2006 b)$, these same drivers may be acting synergistically to promote the disease. In the long-term, an understanding of how individual pathogens and pathogenic communities interact with their hosts to cause disease will require physiological investigations of these pathogens in the laboratory. The first step will be identification of the pathogen(s).

In the present study we analyzed BBD microbial communities from a single coral host species, Siderastrea siderea, using samples from 2 reefs in St. Croix, US Virgin Islands (USVI), 2 reefs in the Bahamas, and one reef in Florida Keys, Florida, USA. One of the 2 sites in St. Croix, Frederiksted, has chronic exposure to large volumes of sewage discharged just meters from the reef. The second St. Croix site, Butler Bay, is nearby but up-current and not exposed to sewage (Kaczmarsky et al. 2005). Field studies have shown that BBD disease prevalence was significantly higher $(2.9 \%)$ in the reef site with direct sewage input as com- 
pared to the second site $(1.0 \%)$ (Kaczmarsky et al. 2005). The other 2 regions, Lee Stocking Island, Bahamas, and the northern Florida Keys, demonstrate comparable nutrient (water column) concentrations as well as BBD prevalence values (0.31 to $0.44 \%$ ) (Voss \& Richardson 2006a). However, while the reefs of Lee Stocking Island are considered pristine, the environmental health of the Florida Keys reefs is a subject of much controversy. Although elevated nutrients (other than associated with upwelling) have not been measured in the water column on the Florida Keys reef tract using analytical chemistry (Leichter et al. 2003), studies of the $\mathrm{N}$ and $\mathrm{P}$ content of macroalgae (Cook et al. 2002) suggest that nutrients from the Keys are reaching the reef.

None of the previous studies of BBD have characterized the microbial community composition (MCC) associated with BBD on a comparative basis targeting a single host species and including sampling from reefs with varying anthropogenic impact. Recently, Voss et al. (2007) used molecular community profiling to study the microorganisms associated with BBD collected from these same 3 Caribbean regions (Lee Stocking Island, Bahamas, Northern Florida Keys and St. John, USVI). In this study the length heterogeneity PCR (LH-PCR) profiling technique was used to assess the MC profiles associated with BBD samples collected from 9 coral species in the 3 regions based on a hypervariable region within the 16S rRNA gene (Mills et al. 2006). Non-metric multidimensional scaling and analysis of similarity (ANOSIM) revealed significant clustering of the profiling data (lengths of hypervariable fragments) by region (Voss et al. 2007). However, this study did not include a more detailed analysis of the composition of the BBD microbial communities available through retrieval and analysis of the full 16S rRNA gene sequences (Voss et al. 2007). The present study expands upon this previous work by examining the $\mathrm{MCC}$ associated with $\mathrm{BBD}$ of a single coral host using 16S rDNA cloning and sequencing. Additionally, in the present study the BBD MCC is compared among reef sites with varying anthropogenic impact (pristine to highly anthropogenic impacted sites) in 3 Caribbean regions (Bahamas, Florida Keys and St. Croix, USVI).

\section{MATERIALS AND METHODS}

Sampling location and collection. Samples of BBD infecting 7 colonies of Siderastrea siderea were collected from 2 reefs near Lee Stocking Island (LSI) in the Exuma Chain of the Bahamas (Horseshoe and Rainbow Garden Reefs), one reef of the Florida Keys (Watson's Reef) and 2 reefs in St. Croix, USVI (Butler Bay and Frederiksted). Details of the sampling sites, sampling dates, number of colonies sampled from each site, depth, water temperature, and sample designation used in the molecular analyses are given in Table 1.

Two Bahamas BBD samples (designated A and B) were collected on Horseshoe Reef from 2 colonies located $7 \mathrm{~m}$ apart, and a third sample (C) from Rainbow Garden Reef. The LSI sites are exposed to relatively low local environmental stress (e.g. no sewage discharge, limited soil erosion, limited fishing activities,

Table 1. Geographic location of sampling sites, number of Siderastrea siderea colonies sampled per site, associated clone library, sampling date, and depth and water temperature for each colony sampled. LSI: Lee Stocking Island; USVI: United States Virgin Islands

\begin{tabular}{|c|c|c|c|c|c|c|}
\hline Reef site & Location & Latitude / longitude & $\begin{array}{c}\text { Colonies } \\
\text { sampled } \\
\text { (clone libary } \\
\text { designation) }\end{array}$ & $\begin{array}{l}\text { Sampling } \\
\text { date }\end{array}$ & $\begin{array}{c}\text { Reef } \\
\text { depth } \\
(\mathrm{m})\end{array}$ & $\begin{array}{l}\text { Water } \\
\text { temp. } \\
\left({ }^{\circ} \mathrm{C}\right)\end{array}$ \\
\hline Horseshoe Reef & LSI, Bahamas & $\begin{array}{r}23^{\circ} 46.18^{\prime} \mathrm{N}, \\
76^{\circ} 8.47^{\prime} \mathrm{W}\end{array}$ & $2\left(\mathrm{~A}^{\mathrm{a}}, \mathrm{B}^{\mathrm{b}}\right)$ & 19 July 2004 & $\begin{array}{l}7.3 \\
8.2\end{array}$ & 27.5 \\
\hline Rainbow Garden Reef & LSI, Bahamas & $\begin{array}{r}23^{\circ} 47.48^{\prime} \mathrm{N}, \\
76^{\circ} 8.47^{\prime} \mathrm{W}\end{array}$ & $1(\mathrm{C})$ & 16 July 2004 & 3.7 & 30.5 \\
\hline Watson's Reef & Florida Keys, FL, USA & $\begin{array}{r}25^{\circ} 9.59^{\prime} \mathrm{N}, \\
80^{\circ} 15.23^{\prime} \mathrm{W}\end{array}$ & 1 (D) & 03 May 2005 & 3.4 & 25.7 \\
\hline Butler Bay Reef site & St. Croix, USVI & $\begin{array}{l}17^{\circ} 75.18^{\prime} \mathrm{N}, \\
64^{\circ} 88.48^{\prime} \mathrm{W}\end{array}$ & $2(\mathrm{E}, \mathrm{G})$ & $\begin{array}{l}22 \text { October 2005, } \\
\text { 01 June } 2005\end{array}$ & $\begin{array}{l}3.0 \\
3.0\end{array}$ & $\begin{array}{l}29.5 \\
30.0\end{array}$ \\
\hline Frederiksted Reef site & St. Croix, USVI & $\begin{array}{l}17^{\circ} 74.00^{\prime} \mathrm{N} \\
64^{\circ} 87.30^{\prime} \mathrm{W}\end{array}$ & $1(\mathrm{~F})$ & 01 June 2005 & 3.0 & 30.0 \\
\hline
\end{tabular}


no pesticide pollution and no river run-off), with the nearest town $45 \mathrm{~km}$ distant and having a low ( 1100) human population (Voss \& Richardson 2006a). Nutrient measurements indicate low values for the waters associated with these reefs (Voss \& Richardson 2006a). One Florida Keys sample (D) was collected from Watson's Reef. While this region is exposed to high human activity (fishing, diving), the reef is several kilometers from shore and any land-generated impacts. The Florida Keys has a high density human population (>77 000) with no central sewage treatment facility. The vast majority of residents use septic tanks. There is much concern that nutrients from this source are affecting the reefs. However, this has not been proven, and it has been suggested that nutrient input is primarily from deep water tidal bores (Leichter et al. 1996). However, based on reports of detection of humanderived (fecal) bacteria and viruses on the reef tract (Paul et al. 1995, 1997, Lipp et al. 2002), we consider the reefs of the Florida Keys as impacted by human activities. Our final 3 samples were collected in St. Croix from the 2 sites discussed previously, i.e. the sewage impacted site near Frederiksted (F) and the nearby non-sewage exposed Butler Bay (E and G). The Butler Bay site is located near a very lightly populated area $4 \mathrm{~km}$ north and upcurrent of the town of Frederiksted (>10000 people). The Frederiksted reef site $(F)$ is located close to the town. Chronic high sewage pollution at this site has been documented previously (Kaczmarsky et al. 2005).

BBD samples were collected in situ using individual sterile $10 \mathrm{ml}$ syringes while SCUBA diving. Within minutes, samples in the syringes typically clump to form a ball approximately $1 \mathrm{~cm}$ in diameter. Upon return to shore the seawater was decanted from syringes and the clumped BBD samples were transferred directly into sterile $2 \mathrm{ml}$ cryovials. All samples were stored at $-20^{\circ} \mathrm{C}$ until further processing.

Extraction of DNA. Genomic DNA was extracted from BBD samples by the bead-beating method using the FastDNA ${ }^{\circledR}$ SPIN Kit for Soil (Qbiogene, Vista, CA) as previously described (Mills et al. 2003, Sekar et al. 2006). The BBD samples were first thawed at room temperature and then either (1) vacuum-filtered onto sterile Versapor@ 200 filters (25 mm diameter, $0.2 \mu \mathrm{m}$ pore size, PALL-Gelman Lab) after which filters and samples were placed directly into Multi-mix lysing Matrix tubes (BIO 101 Systems, Q-Biogene) and processed for DNA extraction; or (2) directly transferred into Multi-mix lysing Matrix tubes using pipette tips with the tips trimmed to enlarge the opening. Samples A to D were processed using the first method and $E$ to $G$ using the second method. To assess the potential for bias associated with the 2 methods, 2 separate clone libraries were constructed using DNA extracted by both methods. Results of a SIMPER (similarity percentages) test (Clarke 1993) using standardized, non-transformed data showed that filtering before DNA extraction had little or no effect on our results with filtered and unfiltered samples more than $80 \%$ similar (MCC).

All BBD samples were bead beaten using the FastPrep $^{\mathrm{TM}}$ instrument (Thermo Electron Corporation) for 20 to $30 \mathrm{~s}$ at a speed of $5.5 \mathrm{~m} \mathrm{~s}^{-1}$ and DNA eluted using 75 to $100 \mu$ sterile nuclease-free water. The DNA was verified by electrophoresis in an agarose gel $(1 \%$, wt/v) along with a TriDye DNA ladder (New England Biolabs) and negative controls, and then stained with ethidium bromide. Subsequently, DNA from each sample was quantified using a fluorometer (Bio-Rad) and, if needed, diluted to a uniform concentration of $10 \mathrm{ng} \mu \mathrm{l}^{-1}$. DNA extracts were stored at $-20^{\circ} \mathrm{C}$ until used for PCR.

$16 S$ rRNA gene amplification, cloning, and sequencing. Bacterial 16S rRNA genes from DNA extracts were PCR amplified using the universal bacterial primers 27F and 1492R (Muyzer et al. 1995) (Integrated DNA Technologies) in a Peltier Thermal Cycler (PTC-200, MJ Research). The final concentration of PCR reactions contained 1X PCR buffer, $2.5 \mathrm{mM}$ $\mathrm{MgCl}_{2}, 0.5 \mathrm{U}$ AmpliTaq Gold ${ }^{\mathrm{TM}}$ DNA polymerase (Applied Biosystems), $0.1 \%$ (w/v) BSA (fraction V, Fisher), $0.25 \mathrm{mM}$ each dNTPs (Promega), $0.5 \mu \mathrm{M}$ forward and reverse primers, and $10 \mathrm{ng}$ of genomic DNA with the final volume made up to $20 \mu$ with nucleasefree water (Fisher). PCR cycling was done as follows: initial denaturing step at $94^{\circ} \mathrm{C}$ for $11 \mathrm{~min}$, followed by 25 cycles of $94^{\circ} \mathrm{C}$ for $1 \mathrm{~min}, 55^{\circ} \mathrm{C}$ for $1 \mathrm{~min}$, and $72^{\circ} \mathrm{C}$ for $1 \mathrm{~min}$ with a final extension step at $72^{\circ} \mathrm{C}$ for $10 \mathrm{~min}$. PCR products were verified by agarose (1\% wt/vol) gel electrophoresis as mentioned above.

Amplified 16S rRNA gene fragments ( 1500 bp) from the BBD DNA extracts were purified with a QIAquick ${ }^{\circledR}$ PCR purification kit (Qiagen). Each purified PCR product was cloned using the TOPO TA cloning kit ${ }^{\circledR}$ version $N$ (Invitrogen) as per the manufacturer's protocol. The cloned products were transformed into the TOP10 chemically competent Escherichia coli and plated onto Luria-Bertani (LB) agar plates containing $50 \mu \mathrm{g} \mathrm{ml}^{-1}$ ampicillin and incubated overnight at $37^{\circ} \mathrm{C}$. Colonies were picked with sterile toothpicks and transferred to 96-well plates containing $50 \mu \mathrm{l}$ of LB broth with ampicillin $\left(50 \mu \mathrm{g} \mathrm{m} \mathrm{m}^{-1}\right)$. The clones were grown overnight at $37^{\circ} \mathrm{C}$ with shaking, and were screened for inserts using M13F and M13R primers (Messing 1983). After verifying the PCR products by gel electrophoresis, the plasmid DNA was extracted (48 to 96 clones from each library) from positive clones grown overnight using QIAPrep ${ }^{\circledR}$ Spin Miniprep Kit (Qiagen). The plasmid inserts were sequenced with an ABI Prism ${ }^{\mathrm{TM}} 3100$ genetic analyzer 
(Applied Biosystems) at the DNA Core Facility at Florida International University using the M13F (Messing 1983) primer. For clones of interest, the full length 16S rRNA gene was sequenced by using the additional primers 518F (Muyzer et al. 1993) and M13R (Messing 1983).

Phylogenetic analysis. All sequences were manually edited using Sequence Analysis ${ }^{\mathrm{TM}}$ (Applied Biosystems) or Sequencher ${ }^{\mathrm{TM}} 4.2 .2$ (GeneCodes) and the full length sequences manually assembled using Sequencher ${ }^{\mathrm{TM}}$ 4.2.2. The partial and full length sequences were first checked for vector contamination (www.ncbi.nlm.nih. gov/VecScreen/VecScreen.html) and for chimeras (Maidak et al. 2001), and then analyzed using the basic local alignment tool (BLAST) queuing system (www. ncbi.nlm.nih.gov/BLAST/) (Altschul et al. 1990) to identify their closest relatives and their tentative phylogenetic positions. The sequence identity matrix was prepared using ClustalX 1.81 and BioEdit programs. Sequences that matched at values of $97 \%$ and above were grouped together and considered as the same operational taxonomic unit (OTU) (Schloss \& Handelsman 2005). Gene sequences that were most closely related to bacteria associated with toxic dinoflagellates were subjected to detailed phylogenetic analysis using the ARB software package (www.arb-home.de) (Ludwig et al. 2004). The sequences were manually aligned in the ARB Edit_Tool by including the closest relatives. Maximum parsimony, neighbor joining, and maximum likelihood phylogenetic analyses were performed and a consensus tree was produced based on maximum-parsimony analysis. The bootstrap analysis (1000 resamplings) was performed to estimate the confidence of the $16 \mathrm{~S}$ rRNA gene tree topology.

Statistical analysis. Species diversity based on clone sequences from all clone libraries was calculated using the Shannon-Wiener $\left(H^{\prime} \log\right.$ e) and Simpson $\left(D_{\text {sim }}\right)$ indices. Species richness was calculated using the Margalef $\left(D_{\text {Mar }}\right)$ richness index. To compare clone libraries between the 3 regions sequence data were analyzed using Bray-Curtis similarity matrices and non-metric multidimensional scaling (NMDS) (Kruskal 1964), and cluster analyses (Clarke \& Warwick 2001). For these analyses, sequences in clone libraries from each sample were organized by major taxonomic group. Data were imported into the Primer 5 software package (www.primer-e.com, Primer-E) and used to calculate Bray-Curtis similarity matrices (Bray \& Curtis 1957). The similarity matrices of different reef sites were assessed by NMDS plots (Kruskal 1964, Clarke 1993) based on the recommendations of Clarke \& Warwick (2001). Bray-Curtis similarity matrices were calculated to compare the microbial communities associated with BBD from the different sites. The nonparametric procedure ANOSIM was used to compare and statistically test the similarity between the unimpacted sites (Bahamas) and the combined grouping of the impacted sites (Florida Keys and St. Croix) based on major phylogenetic group composition (Clarke et al. 2005). Data were 4 th root transformed to deemphasize the contribution of abundant species. SIMPER (similarity percentages) analysis was also used to determine similarity between microbial assemblages and to identify which group contributed most to the similarity between samples (Clarke 1993). The non-parametric Mann-Whitney $U$-test was used to determine if there were significant differences between the impacted and unimpacted groupings for each of the major phylogenetic categories.

Nucleotide sequence accession numbers. The partial and full-length nucleotide sequences determined in this study have been deposited in the GenBank database under the following accession numbers: DQ445996 to DQ446177; DQ644005 to DQ644020; and EF123282 to EF123582.

\section{RESULTS}

\section{Microbial community composition in BBD from different regions of the Caribbean}

\section{Bahamas: Horseshoe and Rainbow Garden Reefs}

Two clone libraries (A and B) were constructed from BBD samples collected from Horseshoe Reef and one library (C) from Rainbow Garden Reef with 95, 47, and 51 partial and full-length 16S rRNA gene sequences obtained, respectively. Species diversity and richness of clone sequences in each library is provided in Table 2. The phylogenetic affiliation of the sequences obtained from all clone libraries is summarized in Fig. 1, and the sequence data are provided in Appendix 1 (available at: www.int-res.com/articles/suppl/m362p085_app.pdf). In the Bahamas clone libraries the Alphaproteobacteria were dominant (64 to $87 \%$ ), followed by Bacteroidetes (3 to $12 \%$ ). The Deltaproteobacteria and Firmicutes represented 3 and $7 \%$ in Clone Library $\mathrm{A}$, and 8 and $4 \%$ in Library $\mathrm{C}$, respectively. However, these sequence types were not observed in Library B (Appendix 1). Members of the Gammaproteobacteria (5\%), spirochetes (3\%) and cyanobacteria (5\%) were only observed in Clone Library $\mathrm{A}$, and were completely absent in Clone Libraries B and C (Appendix 1).

Within these clone libraries, members of the Rhodobacterales were dominant among Alphaproteobacteria followed by Rhizobiales (Fig. 2, Appendix 1). Three sequences of Desulfobacteraceae bacterium (AJ582696) and 4 sequences of Desulfovibrio baarsii (AF418174) (sulfate-reducing Deltaproteobacteria) were found in 
Table 2. Species diversity and richness of clone sequences from Siderastrea siderea black band disease (BBD) clone libraries

\begin{tabular}{|lccc|}
\hline Clone library & $\begin{array}{c}\text { Shannon-Wiener } \\
\left(H^{\prime}\right) \text { index }\end{array}$ & $\begin{array}{c}\text { Simpson } \\
\left(D_{\text {sim }}\right) \text { index }\end{array}$ & $\begin{array}{c}\text { Margalef } \\
\left(D_{\text {Mar }}\right) \text { index }\end{array}$ \\
\hline $\begin{array}{l}\text { A - Horseshoe Reef, } \\
\text { Bahamas }\end{array}$ & 3.7 & 0.96 & 11.0 \\
$\begin{array}{l}\text { B - Horseshoe Reef, } \\
\text { Bahamas }\end{array}$ & 2.7 & 0.91 & 5.5 \\
$\begin{array}{l}\text { C - Rainbow Garden Reef, } \\
\text { Bahamas }\end{array}$ & 2.7 & 0.90 & 5.3 \\
$\begin{array}{l}\text { Florida Keys, FL, USA } \\
\text { E - Butler Bay Reef site, } \\
\text { St. Croix, USVI }\end{array}$ & 3.2 & 0.95 & 7.9 \\
$\begin{array}{l}\text { F - Frederiksted Reef site, } \\
\text { St. Croix, USVI }\end{array}$ & 3.5 & 0.97 & 9.1 \\
$\begin{array}{l}\text { G - Butler Bay Reef site, } \\
\text { St. Croix, USVI }\end{array}$ & 3.3 & 0.96 & 11.0 \\
\hline
\end{tabular}
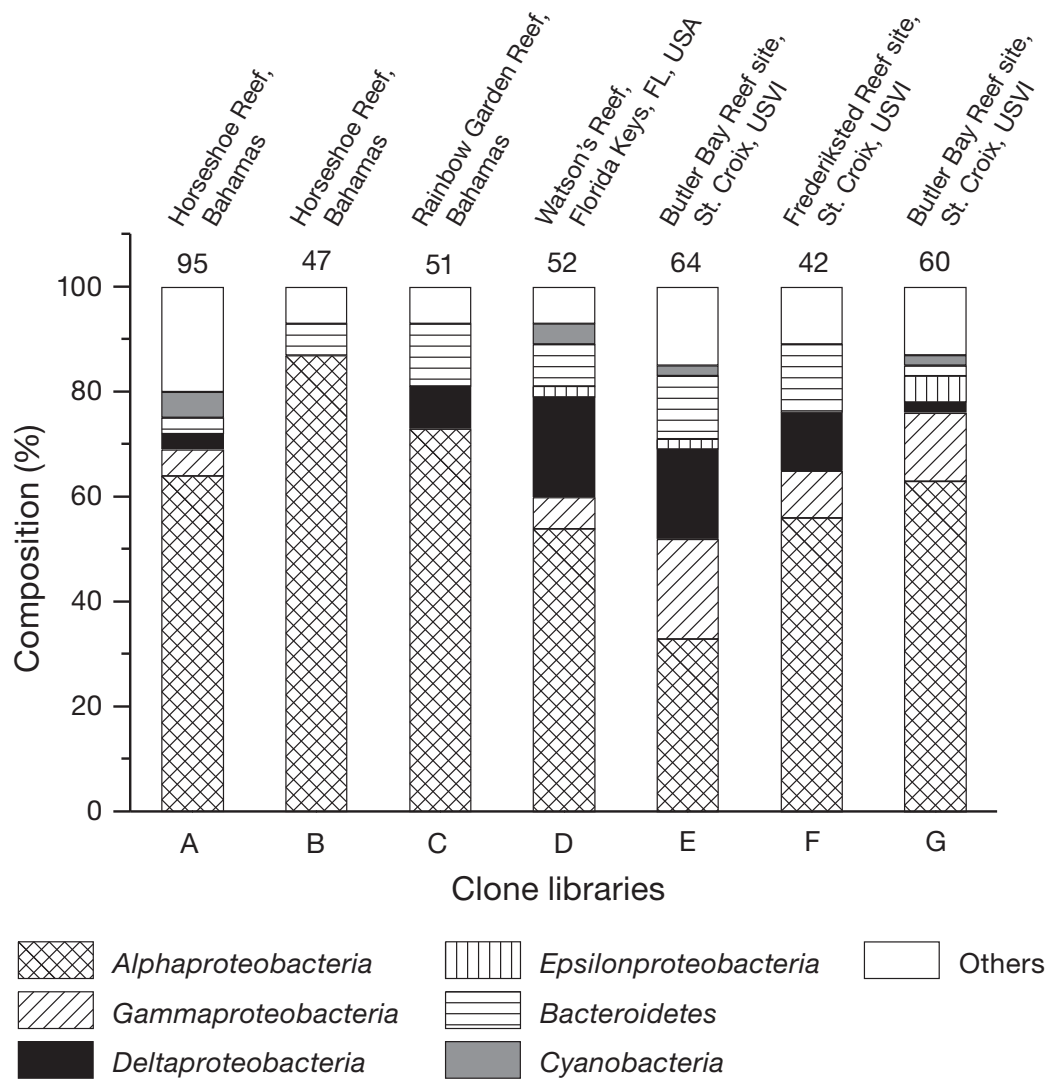

Epsilonproteobacteria

Bacteroidetes

Cyanobacteria

Fig. 1. Most dominant bacterial phylogenetic groups (based on 16S rRNA gene sequence types) present in 7 clone libraries produced from black band disease on Siderastrea siderea. Numbers above bars: numbers of sequences in respective clone libraries. Clone library designations and sampling sites are also presented. Some (48) of the sequences from clone library A and all (47) of the sequences from Clone Library B have been published as Clone Libraries BBD-216 and BBD-217, respectively (Sekar et al. 2006)
Clone Libraries A and C, respectively. Sequences related to the cyanobacteria Lyngbya hieronymussi var. hieronymussi (AB045906) and Synechococcus sp. Dim (AY172803) were found in Clone Library A.

Florida Keys: Watson's Reef

In this sample (Library D), the Alphaproteobacteria were again dominant (54\%) among all sequences followed by Deltaproteobacteria (19\%) and Bacteroidetes (8\%) (Fig. 1). Between 4 and $6 \%$ of the sequences were affiliated with Gammaproteobacteria, Firmicutes and cyanobacteria and $2 \%$ each were affiliated with Epsilonproteobacteria, Deferribacteres and Verrucomicrobia (Appendix 1). In this library, within the Alphaproteobacteria, the numbers of Rhizobiales were comparable to Rhodospirillales and Rhodobacterales (Fig. 2).

Ten sequences were affiliated with Deltaproteobacteria, 9 of which most closely matched the sulfatereducing bacteria Desulfovibrionales and Desulfobacterales (Appendix 1). Cyanobacteria represented $4 \%$ of the total sequences ( 2 of 52 clones). One full sequence (1528 bp) was a close match (99\% sequence similarity) to the BBD-associated cyanobacterium LR-3L (AF474001), a member of the genus Geitlerinema (Cooney et al. 2002, Ragoonath 2005).

\section{St. Croix, USVI: Butler Bay and Frederiksted reef sites}

In these clone libraries ( $E, F$ and $G$ ) the Alphaproteobacteria represented 33 to $63 \%$ of the total sequences, followed by 9 to $19 \%$ of Gammaproteobacteria, 2 to $17 \%$ of Deltaproteobacteria and 2 to $13 \%$ of Bacteroidetes (Fig. 1). Cyanobacteria represented $2 \%$ of the total sequences in the $\mathrm{E}$ and $\mathrm{G}$ libraries, and were absent in Clone Library F (Appendix 1).

Rhodobacterales dominated the Alphaproteobacteria in the 3 St. Croix 


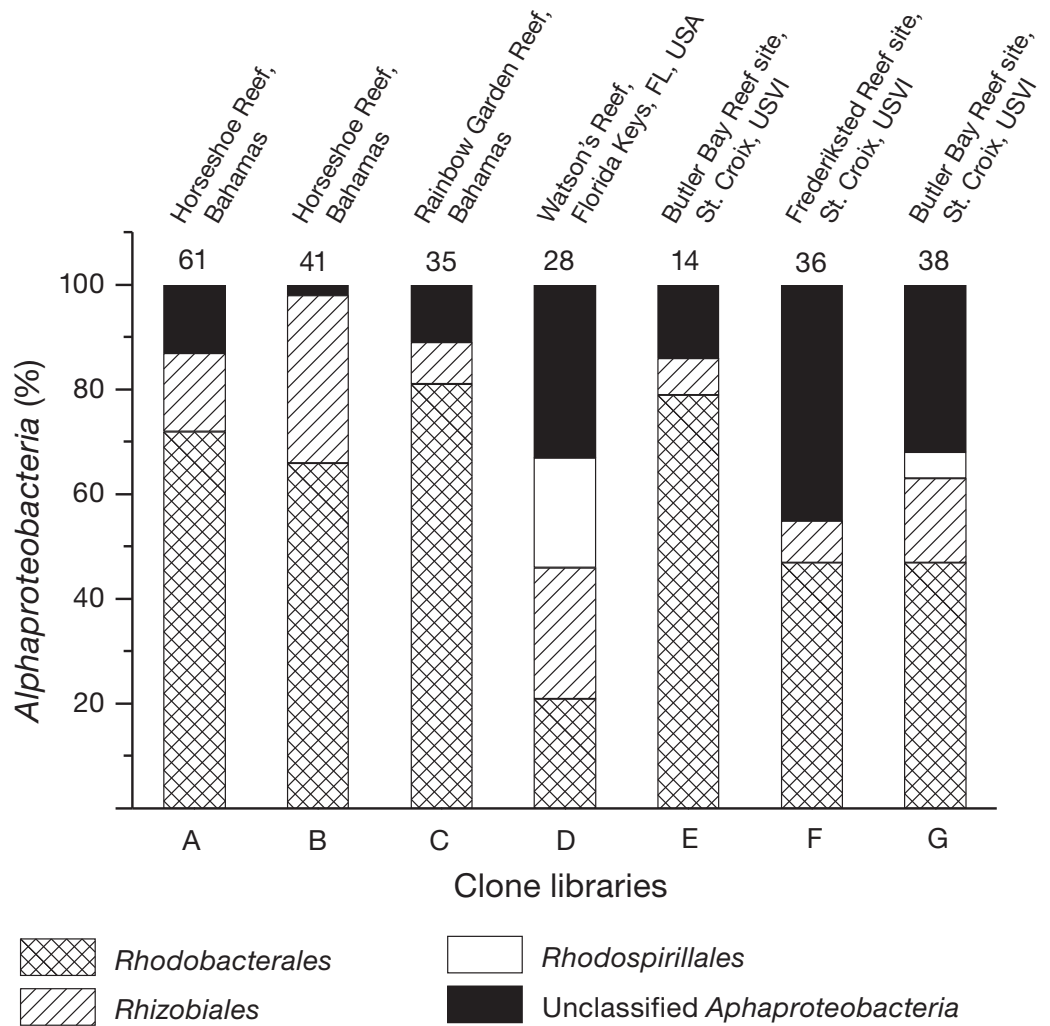

Fig. 2. 16S rRNA gene sequences affiliated with the Rhodobacterales, Rhizobiales, Rhodospirillales and unclassified Alphaproteobacteria present in 7 clone libraries produced from black band disease on Sidereastrea siderea. Numbers above the bars give the numbers of alphaproteobacterial sequences in the respective clone libraries the Frederiksted (F) and Florida Keys (D) samples and between the 2 samples (E and G) from the unimpacted Butler Bay sites. Again the Bahamas samples were less tightly clustered, at about $67 \%$ similarity.

Further statistical analysis, in which sequences from the St. Croix and Florida Keys samples were grouped and compared to the Bahamas samples, showed a significant difference (ANOSIM, Global R=0.556, p = 0.029). SIMPER analysis was then carried out to compare the similarities between these 2 groupings and to determine which phylogenetic groups contributed most to the differences. Samples from the impacted sites were on average $85 \%$ similar, with Alphaproteobacteria contributing 23\%, Gammaproteobacteria $15 \%$, Deltaproteobacteria $14 \%$ and Bacteroidetes $13 \%$. Samples from the unimpacted Bahamas sites were $66 \%$ similar, with Alphaproteobacteria contributing $49 \%$ and Bacteroidetes $24 \%$. The average dissimilarity between the impacted and unimpacted sites was $31 \%$. The statistically largest contributors to the differences were the Gammaproteobacteria (21\%) and the clone libraries (Fig. 2). Unlike the clone libraries from the Bahamas and the Florida Keys, the St. Croix clone libraries included many members of the Gammaproteobacteria (Fig. 1, Appendix 1), with sulfate reducers from this group present in each of the 3 libraries. In Clone Library G, 3 sequences (1508 to 1527 bp, EF123477 to 79) were detected with $90 \%$ homology to Beggiatoa sp. 'Bay of Concepcion', Thiotrichales (AF035956).

\section{Regional comparison of BBD associated with Siderastrea siderea}

NMDS results (Fig. 3) revealed a tight clustering of the Florida Keys (D) and sewage impacted Frederiksted (St. Croix) samples (F) and a tight clustering of the 2 samples from the up-current St. Croix site (E and G). While the Bahamian samples (A, B and C) are distinctly separate from the other samples, they appear to be highly variable, which agrees with earlier findings from molecular analysis of BBD from these reefs (Voss et al. 2007). Cluster analysis (not shown) revealed a similar pattern, with 87 to $90 \%$ similarities between

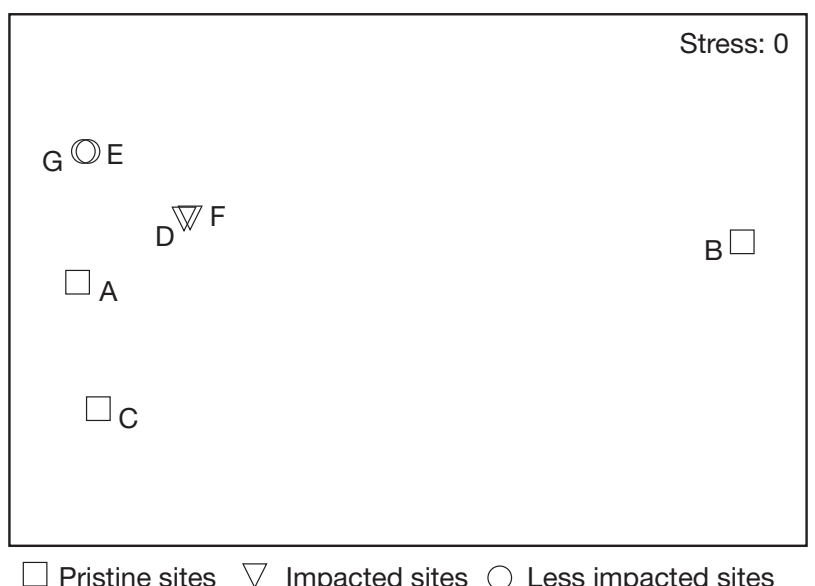

Fig. 3. Non-metric multidimensional scaling plot for the standardized transformed (4th root) abundance of major phylogenetic groups from each sample (stress $=0$ ). D and F: highly impacted sites in Florida Keys, FL, USA, and St. Croix, USVI, respectively; E and G: less impacted sites in St. Croix; A, B and C: unimpacted (pristine) sites in the Bahamas. Regions are indicated by different symbols. Clarke (1993) suggests the following guidelines for acceptable stress values: $<0.05=$ excellent,$<0.10=$ good, $0.20=$ usable, $>0.20=$ not acceptable 


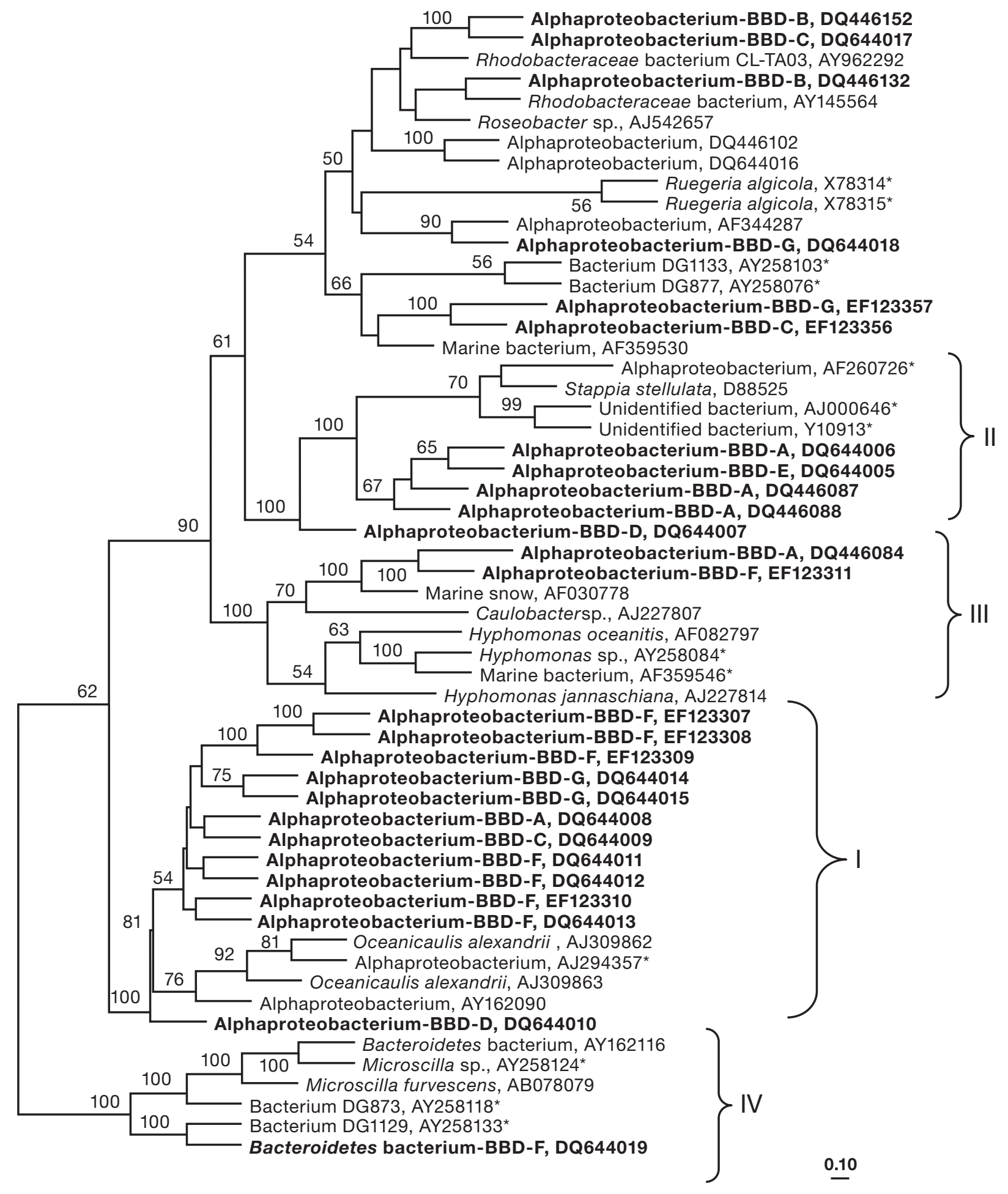

Fig. 4. Phylogenetic tree derived from black band disease (BBD)-derived 16S rRNA gene sequences closely related to bacteria associated with toxin producing dinoflagellates and their neighbors. Bold: sequences from the present study, including designation of the source clone library (BBD-A to BBD-G). Clusters I to IV: sequences from the present study affiliated with different distinct clusters. ${ }^{*}$ Sequences related to bacteria associated with toxin producing dinoflagellates in the GenBank database. Tree topology is based on the maxium-parsimony analysis. Scale bar: $10 \%$ estimated sequence divergence. Numbers at the nodes are bootstrap values (percentages) obtained after 1000 resamplings. Bootstrap values of $<50 \%$ are not shown 
Deltaproteobacteria (14\%), which were both more abundant in the impacted sites. The Mann-Whitney $U$-test also showed significantly higher numbers of Alphaproteobacteria in the samples from the unimpacted sites, and of Gammaproteobacteria in the samples from the impacted sites $(\mathrm{p}<0.05$ for both comparisons). The impacted sites were significantly different from the unimpacted sites.

\section{Sequence types of bacteria associated with toxic dinoflagellates}

A total of 26 clone sequences (Appendix 1, designated by footnotes), from all 3 regions, were related (96 to $99 \%$ similarity by BLAST analysis) to bacteria associated with paralytic shellfish toxin (PST)-producing dinoflagellates. Phylogenetic analysis showed that 20 of these sequences grouped into 4 distinct clusters, designated as Clusters I to IV (Fig. 4). Twelve sequences from all 3 regions were closely related (98 to $99 \%$ similarity by BLAST analysis) to an uncultured Alphaproteobacterium (AJ294357) associated with the toxic dinoflagellate Alexandrium sp. (Appendix 1). This finding was confirmed by detailed phylogenetic analysis (Fig. 4, Cluster I). The clone library from the polluted site in St. Croix (F) had the highest number of clones with this sequence type ( $n=7,11 \%$ of clones), followed by Clone Library $\mathrm{G}(\mathrm{n}=2$, also from St. Croix). The Bahamas and Florida Keys Clone Libraries A, C and D each had one such sequence (Appendix 1, Fig. 4). Five sequences, 3 from the Bahamas (Clone Library A, DQ446087, DQ446088 and DQ644006), one from the Florida Keys, DQ644007) and one from St. Croix (library E, DQ644005) were closely related (94 to $97 \%$ similarity) to the Alphaproteobacterium (AF260726) associated with the toxic dinoflagellate Alexandrium tamarense (Appendix 1), with this identification confirmed by phylogenetic analysis (Fig. 4, Cluster II).

In Clone Libraries A and F, 2 sequences (DQ446084, and EF123311, respectively) were closely related (98\% similarity) to an Alphaproteoacterium (AY701434) associated with the toxic dinoflagellate Gymnodinium catenatum (Appendix 1). Phylogenetic analysis confirmed that the 2 sequences were closely related to the Hyphomonas group of bacteria, some members of which are associated with toxic dinoflagellates (AY258 084 and AF359546) (Fig. 4, Cluster III). In the clone library from the polluted St. Croix site $(\mathrm{F})$, a sequence (DQ644019) was related (98\% similarity) to a Bacteroidetes bacterium (AY701462) associated with a toxic dinoflagellate (Appendix 1). Phylogenetic analysis showed that the sequence was related to the bacteria (AY258133, AY258188 and AY258124) associated with PST producing G. catenatum (Fig. 4, Cluster IV).

\section{DISCUSSION}

\section{Physiological and ecological aspects of BBD microbial communities}

High microbial diversity was found in BBD on the host Sidereastrea siderea in all 3 regions in this study (Table 2) with the Alphaproteobacteria dominating all clone libraries irrespective of the sampling location (Fig. 1). This finding is in agreement with earlier molecular studies on BBD-associated microbes (Cooney et al. 2002, Frias-Lopez et al. 2002, Sekar et al. 2006). Among the Alphaproteobacteria, members of the Rhodobacterales dominated almost all of the clone libraries (except Florida Keys, D) (Fig. 2). Previous molecular (sequencing) studies showed that members of the Roseobacter clade (order Rhodobacterales) are numerically dominant in the BBD community (FriasLopez et al. 2002, Sekar et al. 2006).

Any specific role in the BBD community of the dominant Alphaproteobacteria is not yet known. Because they are not well represented in healthy coral mucus and coral tissue, it is worth noting the abundance of Roseobacter clade members in BBD samples. The Roseobacter clade is reported to be well represented in diverse microbial habitats like seawater, algal blooms, microbial mats, sediments, sea ice and marine invertebrates (Buchan et al. 2005, Wagner-Dobler \& Biebl 2006). It has been reported that many of the Roseobacter clade members are involved in the global carbon and sulfur cycles, symbiosis, the production of secondary metabolites, and as animal disease causing agents (Buchan et al. 2005, Wagner-Dobler \& Biebl 2006, Martens et al. 2007). A recent study (Bruhn et al. 2007) showed that many of the Roseobacter species produce antibacterial compounds that inhibit nonRoseobacter species, which may contribute to the dominance of members of this clade in diverse environments, including BBD. It may be that the common presence of Alphaproteobacteria in BBD is a direct result of the presence of an active sulfur cycle, an integral part of the band's ecology (Carlton \& Richardson 1995).

Sequence types related to the Gammaproteobacteria were found in most ( 5 of 7 ) of the libraries, and represented a higher percentage of clones in the St. Croix clone libraries (9 to $19 \%$ ) as compared to the Bahamas and Florida Keys clone libraries (0 to $6 \%$ ). Although most of the gammaproteobacterial sequence types found in the clone libraries were related to uncultured Gammaproteobacteria, sequences belonging to the orders Chromatiales, Xanthomonadales, Thiotrichales, Oceanospirillales, Pseudomonadales, Altermonadales and Vibrionales were detected. Many members of the Thiotrichales (e.g. Thiomicrospira and Beggiatoa) are 
chemolithotrophic sulfur-oxidizers and some members of Pseudomonadales (e.g. Pseudomonas spp.) are phototrophic sulfur-oxidizers (Sievert et al. 2007). Within this group, members of Vibrionales have been found to be associated with marine animal diseases (Kushmaro et al. 2001, Ben-Haim et al. 2003, Rosenberg \& Falkovitz 2004). Recently, Barneah et al. (2007) reported the presence of several sequences related to Vibrio spp. in BBD samples from Red Sea stony corals. As with the Alphaproteobacteria, the common observation of members of the Gammaproteobacteria in BBD may be based on the presence of the active sulfur cycle. In particular, the steep opposing gradients of oxygen and sulfide present within the $1 \mathrm{~mm}$ thick band would demand very active biological sulfide oxidation. It has been shown that chemical sulfide oxidation would not allow for the persistence of microprofiles of this type (Jørgensen 1982).

Three of the Gammaproteobacteria sequence types found in one of the clone libraries (G) (Appendix1) were most closely related ( $90 \%$ homology) to Beggiatoa sp. (AF035956). Although detailed phylogenetic analysis did not confirm their identity, this is the first molecular study to show the presence of sequences most closely related (by BLAST analysis) to Beggiatoa in BBD samples. This is important because although earlier molecular studies did not detect Beggiatoa, they appear abundant microscopically in fresh BBD samples (Rützler et al. 1983, Richardson 1996). Beggiatoa are wellknown sulfide-oxidizers. Members of this genus actively migrate with the oxygen/sulfide interface and are thought to be important in stabilizing the sulfide dynamics in sulfide-rich microbial mats (Jørgensen 1982).

An important microbial group consistently represented in BBD based on both classical and molecular methods are the sulfate reducing genera of the Deltaproteobacteria (Cooney et al. 2002, Frias-Lopez et al. 2002, Sekar et al. 2006, Viehman et al. 2006, Barneah et al. 2007). As within other studies, the Deltaproteobacteria were represented in relatively high percentages (11 to $19 \%$ ) in the Florida Keys and 2 of the St. Croix clone libraries. (Appendix 1). The Desulfovibrio spp. appear to be integral to BBD ecology in that the byproduct of sulfate reduction, sulfide, has been shown to be toxic to corals at levels present in the band (Richardson et al. 1997) and as it is also toxic to many microorganisms, including most cyanobacteria, sulfide tolerance appears to be a requirement for each member of the BBD consortium. It has, in fact, been demonstrated that BBD cyanobacteria isolated into culture (to date, members of the genera Geitlerinema and Leptolyngbya) exhibit sulfide-resistant oxygenic photosynthesis, a relatively rare capability (Myers et al. 2007).

While the MCC of BBD is consistently complex and dominated by the members discussed above, it is also routinely distinct from the surface mucopolysaccharide layer (SML) of corals. In a previous study by our group that also targeted Siderastrea siderea on reefs of Lee Stocking Island (Sekar et al. 2006) we found the SML clone libraries to be dominated by Gammaproteobacteria, followed by Betaproteobacteria, Alphaproteobacteria, Firmicutes, Bacteroidetes and Epsilonproteobacteria. No cyanobacteria related sequence types were observed in the SML clone libraries. In the present study, the microbial communities associated with the water column were not characterized. However, in an earlier study Frias-Lopez et al. (2002) compared the microbial communities associated with seawater and the healthy, BBD and dead coral surfaces of 3 Caribbean corals (Montastrea annularis, M. cavernosa and Diploria strigosa). Their results showed that the clone libraries of overlying water were dominated by cyanobacteria followed by Gammaproteobacteria and Alphaproteobacteria. The clone libraries from healthy coral tissues from $M$. cavernosa and $D$. strigosa were dominated by Gammaproteobacteria while healthy tissue clone libraries of $M$. annularis were dominated by green sulfur bacteria, Alphaproteobacteria, Firmicutes and Planctomycetes. Their results also showed that BBD associated microbial communities were distinct from those associated with healthy coral tissues (FriasLopez et al. 2002), which agrees with our previous report (Sekar et al. 2006).

\section{Anthropogenic influences on BBD-associated microbial communities}

NMDS and cluster analysis of the sequence data from this study showed clustering of BBD microbial communities by level of anthropogenic impact. The Florida Keys (D) and St. Croix sewage impacted site (F) grouped together (87\% similar) and the 2 up-current, less impacted sites in St. Croix (90\% similar) grouped together. The less impacted sites in the Bahamas showed different grouping with $67 \%$ similarity. The previous study by our group (Voss et al. 2007) that used LH-PCR community profiling of BBD-associated microbes in these same 3 regions (LSI, several reefs of the northern Florida Keys, and St. John, USVI) produced similar results, i.e. statistically significant regional differences in the BBD community profiles. Thus, the sequence-based data analysis presented here is in concurrence with the community profiling data.

In previous monitoring studies, reefs of Lee Stocking Island have exhibited the lowest BBD prevalence values $(0.31 \%$ for the entire scleractinian coral population) for any of the 3 regions studied. The most susceptible species, Colpophyllia natans and Siderastrea 
siderea, were shown to be infected at much higher rates of 7.6 and $2.4 \%$ respectively (Voss \& Richardson 2006a). Recent Florida Keys data show slightly higher BBD prevalence values of $0.44 \%$ for all scleractinian coral colonies, and $8.3 \%$ for the most susceptible species Meandrina meandrites (Voss 2006). Previous BBD data from Grecian Rocks in the Florida Keys in the 1990s revealed BBD prevalence for all susceptible species as high as $12.2 \%$ (Kuta \& Richardson 1996). Comparison of BBD prevalence values at St. Croix's impacted $(F)$ site with its unimpacted site showed significant differences both in 2001 (Kaczmarsky et al. 2005) and 2005 (L. T. Kaczmarsky unpubl. data). In these 2 years, the sewage impacted site had significantly more BBD for all susceptible species than the unimpacted site (2.9 vs. $1.0 \%$ in 2001 and 2.2 vs. $0.8 \%$ in 2005, $\alpha=0.05$ for both years). This trend held for the most affected species, Diploria clivosa (15.8 vs. $2.5 \%$ and 15.4 vs. $0.6 \%$ respectively, $\alpha=0.05$ for both years; Kaczmarsky et al. 2005 and unpubl. data).

Although the present study did not include water quality data, this information is available in databases. To interpret our regional comparison results we retrieved water quality data for the Florida Keys from Florida International University's Southeast Environmental Research Center (http://serc.fiu.edu/ wqmnetwork) and from the U.S. Environmental Protection Agency (www.epa.gov/storet/dw_home.html). Water quality data for St. Croix were obtained from U.S. Environmental Protection Agency (www.epa. gov/storet/dw_home.html) and in other studies by our group (Kaczmarsky et al. 2005 and unpubl.).

The databases indicate that nearshore Florida Keys surface waters exhibit a median $\mathrm{TN}$ of $13 \mu \mathrm{M}$ with a maximum value of $86 \mu \mathrm{M}(\mathrm{n}=478)$. TP has a median value of 0.02 and a maximum of $0.62 \mu \mathrm{M}(\mathrm{n}=478)$. One published study (Sullivan-Sealey 2004) on nutrient levels measured on nearshore patch reefs in the Bahamas Exuma Cays, such as reefs of Lee Stocking Island, indicated values that were lower (median total nitrogen, TN, values during February $(\mathrm{n}=60)$ and October $(\mathrm{n}=$ 53) were 3.5 and $6.9 \mu \mathrm{M}$ and TP values were 0.06 and $0.00 \mu \mathrm{M}$, respectively) than the TN and total phosphorus (TP) recorded for nearshore Florida Keys (Jones \& Boyer 2002). For our study reefs in St. Croix limited sampling showed TN for both our sites at slightly less than $22 \mu \mathrm{M}$ (L. T. Kaczmarsky unpubl. data). However, these samples were not collected during a sewage bypass event, which occurs regularly at the F site. In contrast, nutrient analyses performed by the Virgin Islands Department of Planning and Natural Resources on a sample collected during a bypass event detected nitrogen (total Kjedahl nitrogen) as high as $162 \mu \mathrm{M}$. This is much higher than the $86 \mu \mathrm{M}$ maximum recorded on Key Largo reef sites.
As discussed previously, it is generally agreed that anthropogenic activities strongly impact the nearshore waters of the Florida Keys (Paul et al. 1995, 1997, Lapointe et al. 1990, Porter et al. 2001, Lipp et al. 2002). However, because of its complexity, not much is known about the dynamics of nearshore pollution making its way to offshore reefs. Earlier reports showed an onshore to offshore gradient clearly implicating an anthropogenic source of high levels of nutrients from land, which likely impact coral communities (Boyer \& Briceno 2006). Lipp et al. (2002) reported evidence of human fecal contamination in corals of the Florida Keys, specifically the presence of bacterial indicators such as fecal coliform bacteria, enterococci and Clostridium perfringens in $66.7 \%$ of coral surface microlayer (CSM) samples of Montastrea annularis, Siderastrea radians, $S$. siderea and Solenastrea bournoni (Lipp et al. 2002). In CSM samples, the fecal indicators were detected in the range of 5 to $1000 \mathrm{CFU}$ $\mathrm{dl}^{-1}$, whereas they were found in very low numbers in the overlying water samples $\left(\leq 2.5 \mathrm{CFU} \mathrm{dl}^{-1}\right)$ (Lipp et al. 2002). Enterovirus, an indicator of human-specific waste, was detected in $93.3 \%$ of the CSM samples whereas they were detected only once in the water column (Lipp et al. 2002).

In St. Croix, seawater fecal coliform and enterococci data collected during several major raw sewage discharge events provided evidence that sewage impacts the reefs of Frederiksted but not the upcurrent Butler Bay sampled in the present study (Kaczmarsky et al. 2005). For example, during a 2003 event fecal coliforms and enterococci measured 1460 and $1880 \mathrm{CFU} \mathrm{dl}^{-1}$ respectively in the Frederiksted site, while in the Butler Bay site they measured 0 and $5 \mathrm{CFU} \mathrm{dl}^{-1}$. Data for Key Largo are available for 2 EPA sampling stations 15.7 and $28.8 \mathrm{~km} \mathrm{SW}$ of our sampling site (www.epa. gov/storet/dw_home.html). These 2 stations averaged fecal coliforms in 2005 of $43(n=49)$ and $33(n=50)$ $\mathrm{CFU} \mathrm{dl}^{-1}$. On 4 occasions CFUs exceeded $200 \mathrm{CFU} \mathrm{dl}^{-1}$ (www.epa.gov/storet/dw_home.html). Similar bacterial indicator data are not available for LSI, Bahamas region.

Our statistical analysis indicated that the largest contributors to the dissimilarity between the impacted and unimpacted sites were the Gamma- and Deltaproteobacteria, which were more abundant at the impacted sites. Members of these groups in the BBD consortium may contain bacteria responsible for contributing to the greater virulence (and higher prevalence) of BBD observed in the impacted sites as they include genera such as Vibrio, many of which are pathogenic, and the (toxic) sulfide producers. It has been reported that Deltaproteobacteria are dominant in both anthropogenically impacted and (oil) polluted waters (Hernandez-Raquet et al. 2006, Webster \& Negri 2006). 
Our statistical analysis also showed a dominance by the Alphaproteobacteria in BBD samples from all sites, and a significantly higher proportion in the community at the unimpacted sites $(p<0.05)$. This is intriguing since we also found a positive correlation between a subgroup of the Alphaproteobacteria, specifically members associated with toxic dinoflagellates, and the impacted sites. There were significantly more clones from the sewage impacted St. Croix site (14.1\%) that were sequence types associated with toxic dinoflagellates than in the other sites $\left(4.9 \% ; \alpha=0.025, \chi^{2}=6.19\right.$, $\mathrm{df}=1$, with Yates correction). It may be that degraded water quality is causing a shift within the population of Alphaproteobacteria to the more toxic representatives of this group.

\section{Toxin associated bacteria in BBD}

To date, there appear to be consistent toxin associated bacteria in BBD. These include the Juvenile Oyster Disease (JOD) pathogen, sulfidogens, toxin producing cyanobacteria, and bacteria associated with toxic dinoflagellates. Two previous molecular studies of the BBD community detected sequences matching Roseovarius crassostreae, the bacterial pathogen associated with JOD (Cooney et al. 2002, Sekar et al. 2006). In the present study this sequence was again found in a large number (15) of clones, with sequence homologies of 94 to $97 \%$, from the Bahamas and St. Croix sites (Appendix 1). This bacterial species has been proposed as a potentially important BBD pathogen (Cooney et al. 2002) and was suggested as a target for studies to determine the primary pathogen of BBD. An isolate was obtained by our laboratory ( $R$. crassostreae ATTC BAA-1102) and tested for its ability to infect Montastrea annularis, another host species of BBD. The results were negative indicating that this species is not the primary pathogen of BBD.

In the present study, as in previous studies, we detected BBD sulfate-reducing (sulfidogenic) bacteria in almost all of our clone libraries (all except the Bahamas Clone Library B). In an earlier study (Richardson et al. 1997), we showed that sulfide was highly toxic to corals and that exposure leads to tissue lysis under anoxic conditions. We have also demonstrated the presence of the cyanotoxin microcystin in BBD samples and have isolated microcystin producing BBD cyanobacteria into culture (Richardson et al. 1997, Myers et al. 2007).

Sequence types matching bacteria associated with toxic dinoflagellates were observed in the clone libraries from all 3 geographic regions and have been reported previously by our group from Bahamas samples (Sekar et al. 2006). These sequences were not observed in the healthy SML of samples of the same coral colonies (Sekar et al. 2006). The present study showed their consistent presence in all the BBD samples examined, irrespective of the sampling location. It is interesting to note that the bacteria associated with toxin producing dinoflagellates were dominant in the sewage exposed site in St. Croix, where BBD prevalence was significantly higher than the unimpacted St. Croix site (2.7 vs. 1.0\%) (Kaczmarsky et al. 2005). Phylogenetic analysis confirmed that at least 20 sequences were related to bacteria associated with the toxic dinoflagellates Alexandrium spp., A. tamarense, Gymnodinium catenatum and Prorocentrum lima. Many of these dinoflagellates are known to produce PST (Groben et al. 2000, Hold et al. 2001a,b, Green et al. 2004, Sala et al. 2005). It has been reported that dinoflagellates (e.g. G. catenatum) produce PST in concentrations of up to $316 \mathrm{fmol}$ per cell and that this concentration varies with the dinoflagellate species and its geographic origin (Green et al. 2004). Bacteria isolated from toxic dinoflagellates are reported to synthesize various amounts of PST, and may contribute directly to the toxicity of dinoflagellates as toxicity is reduced when the bacteria are removed from dinoflagellate cultures (Groben et al. 2000). The presence of toxic dinoflagellate-associated bacteria in the BBD microbial mat may create localized toxic microenvironments within the BBD environment in addition to toxic sulfide (and potentially cyanotoxin) found throughout the band.

\section{CONCLUSIONS}

Our results strengthen the proposal that BBD consists of microorganisms that fall within 4 specific physiological groups and 3 (to date) categories of toxin producers. While the individual species within these groups may vary, it appears that the functioning of BBD may be dependent on the roles individual members within these groups play in terms of tolerance to sulfide, the ability to withstand exposure to widely fluctuating chemical environments, and the ability to withstand (and produce) multiple toxins. Furthermore, we propose that with degrading water quality certain proteobacteria thrive and increase BBD virulence.

Acknowledgements. This research was funded by National Institutes of Health (NIH/NIGMS SO6GM8205), NOAA's Caribbean Marine Research Center (CMRC-04-PRJV-0104C) and NOAA's National Undersea Research Center/ UNCW (FKRP-2004-11). We thank T. Zimmerman, Agricultural Experiment Station, University of the Virgin Islands, Project AWARE and ScubaWest Dive shop for their support. We also thank E. Remily for technical assistance in the laboratory, J. Voss for Bahamas field sampling and T. Rawlings for helpful comments on phylogenetic analysis. 


\section{LITERATURE CITED}

Altschul SF, Gish W, Miller W, Meyers EW, Lipman DJ (1990) Basic local alignment search tool. J Mol Biol 215:403-410

Amann RI, Ludwig W, Schleifer KH (1995) Phylogenetic identification and in situ detection of individual microbial cells without cultivation. Microbiol Rev 59:143-169

Antonius A (1973) New observations on coral destruction in reefs. Proc 10th Meet Assoc Isl Mar Lab Caribbean University of Puerto Rico, Mayaguez, p 3

Antonius A (1981) The 'band' diseases in coral reefs. In: Gomez ED (ed) The reef and man. Proc 4th Int Coral Reef Symp. Marine Sciences Center, University of Philippines, Quezon City, p 7-14

Barneah O, Ben-Dov E, Kramarsky-Winter E, Kushmaro A (2007) Characterization of black band disease in Red Sea stony corals. Environ Microbiol 9:1995-2006

Ben-Haim Y, Thompson FL, Thompson CC, Cnockaert MC, Hoste B, Swings J, Rosenberg E (2003) Vibrio coralliilyticus sp. nov., a temperature-dependent pathogen of the coral Pocillopora damicornis. Int J Syst Evol Microbiol 53: 309-315

Boyer JN, Briceno HO (2006) FY2006 cumulative report to the South Florida water management district. South Flrodia coastal water quality monitoring network. Southeast Environmental Research Center, Florida International University, Miami, FL

Bray JR, Curtis JT (1957) An ordination of the upland forest communities of southern Wisconsin. Ecol Monogr 34:77-87

Bruhn JB, Gram L, Belas R (2007) Production of antibacterial compounds and biofilm formation by Roseobacter species are influenced by culture conditions. Appl Environ Microbiol 73:442-450

Buchan A, Gonzalez JM, Moran MA (2005) Overview of the marine Roseobacter lineage. Appl Environ Microbiol 71: 5665-5677

Carlton RG, Richardson LL (1995) Oxygen and sulfide dynamics in a horizontally migrating cyanobacterial mat: black band disease of corals. FEMS Microbiol Ecol 18:155-162

Clarke KR (1993) Non-parametric multivariate analyses of changes in community structure. Aust J Ecol 18:117-143

Clarke KR, Warwick RM (2001) Changes in marine communities: an approach to statistical analysis and interpretation, 2nd edn. PRIMER-E, Plymouth

Clarke KR, Warwick RM, Somerfield PJ, Gorley RN (2005) Change in marine communities: an approach to statistical analysis and interpretation, 3rd edn. PRIMER-E, Plymouth

Cook CB, Mueller EM, Ferrier MD, Annis E (2002) The influence of nearshore waters on corals of the Florida reef tract. In: Porter J, Porter K (eds) The Everglades, Florida Bay, and coral reefs of the Florida Keys: an ecosystem sourcebook. CRC Press, Boca Raton, FL, p 771-788

Cooney RP, Pantos O, Tissier MDAL, Barer MR, O'Donnell AG, Bythell JC (2002) Characterization of the bacterial consortium associated with black band disease in coral using molecular microbiological techniques. Environ Microbiol 4:401-413

> Ducklow HW, Mitchell R (1979) Observations on naturally and artificially diseased tropical corals: a scanning electron microscopy study. Microb Ecol 5:215-223

Frias-Lopez J, Zerkle AL, Bonheyo GT, Fouke BW (2002) Partitioning of bacterial communities between seawater and healthy, black band diseased, and dead coral surfaces. Appl Environ Microbiol 68:2214-2228

Frias-Lopez J, Bonheyo GT, Jin QS, Fouke BW (2003) Cyanobacteria associated with coral black band disease in Caribbean and Indo-Pacific Reefs. Appl Environ Microbiol 69: $2409-2413$
Frias-Lopez J, Klaus JS, Bonheyo GT, Fouke BW (2004) Bacterial community associated with black band disease in corals. Appl Environ Microbiol 70:5955-5962

Green EP, Bruckner AW (2000) The significance of coral disease epizootiology for coral reef conservation. Biol Conserv 96:347-361

Green DH, Llewellyn LE, Negri AP, Blackburn SI, Bolch CJS (2004) Phylogenetic and functional diversity of the cultivable bacterial community associated with the paralytic shellfish poisoning dinoflagellate Gymnodinium catenatum. FEMS Microbiol Ecol 47:345-357

Groben R, Doucette GJ, Kopp M, Kodama M, Amann R, Medlin LK (2000) 16S rRNA targeted probes for the identification of bacterial strains isolated from cultures of the toxic dinoflagellate Alexandrium tamarense. Microb Ecol 39:186-196

> Harvell CD, Kim K, Burkholder JM, Colwell RR and others (1999) Review: marine ecology emerging marine diseases - climate links and anthropogenic factors. Science 285:1505-1510

> Hernandez-Raquet G, Budzinski H, Caumette P, Dabert P, Le Menach K, Muyzer G, Duran R (2006) Molecular diversity studies of bacterial communities of oil polluted microbial mats from the Etang de Berre (France). FEMS Microbiol Ecol 58:550-562

> Hold GL, Smith EA, Birkbeck TH, Gallacher S (2001a) Comparison of paralytic shellfish toxin (PST) production by the dinoflagellates Alexandrium lusitanicum NEPCC 253 and Alexandrium tamarense NEPCC 407 in the presence and absence of bacteria. FEMS Microbiol Ecol 36:223-234

Hold GL, Smith EA, Rappe MS, Maas EW and others (2001b) Characterisation of bacterial communities associated with toxic and non-toxic dinoflagellates: Alexandrium spp. and Scrippsiella trochoidea. FEMS Microbiol Ecol 37:161-173

Jones R, Boyer JN (2002) FY2001 annual report of the water quality monitoring project for the water quality program in the Florida Keys national marine sanctury. Tech Report T181. Southeast environmental research center, Florida International University, Miami, FL

Jørgensen BB (1982) Ecology of the bacteria of the sulphur cycle with special reference to anoxic-oxic interface environments. Philos Trans R Soc Lond B Biol Sci 298:543-561

Kaczmarsky LT, Draud M, Williams EH (2005) Is there a relationship between proximity to sewage effluent and the prevalence of coral disease? Caribb J Sci 41:124-137

Koch R (1884) Die Aetiologie der Tuberkulose. Mitt Kaiser Gesundh 2:1-88

Kruskal JB (1964) Multidimensional scaling by optimizing goodness of fit to a nonmetric hypothesis. Psychometrika 29:1-27

> Kushmaro A, Banin E, Loya Y, Stackebrandt E, Rosenberg E (2001) Vibrio shiloi sp. nov., the causative agent of bleaching of the coral Oculina patagonica. Int J Syst Evol Microbiol 51:1383-1388

Kuta KG, Richardson LL (1996) Abundance and distribution of black band disease on coral reefs in the northern Florida Keys. Coral Reefs 15:219-223

Kuta KG, Richardson LL (2002) Ecological aspects of black band disease of corals: relationships between disease incidence and environmental factors. Coral Reefs 21:393-398

Lapointe BE, Oconnell JD, Garrett GS (1990) Nutrient couplings between on-site sewage disposal systems, groundwaters, and nearshore surface waters of the Florida Keys. Biogeochemistry 10:289-307

Leichter JJ, Wing SR, Miller SL, Denny MW (1996) Pulsed delivery of subthermocline water to Conch Reef (Florida Keys) by internal tidal bores. Limnol Oceanogr 41: 1490-1501 
Leichter JJ, Stewart HL, Miller SL (2003) Episodic nutrient transport to Florida coral reefs. Limnol Oceanogr 48: 1394-1407

Lipp EK, Jarrell JL, Griffin DW, Lukasik J, Jacukiewicz J, Rose JB (2002) Preliminary evidence for human fecal contamination in corals of the Florida Keys, USA. Mar Pollut Bull 44:666-670

Ludwig W, Strunk O, Westram R, Richter L and others (2004) ARB: a software environment for sequence data. Nucleic Acids Res 32:1363-1371

Maidak BL, Cole JR, Lilburn TG, Parker CT and others (2001) The RDP-II (Ribosomal Database Project). Nucleic Acids Res 29:173-174

Martens T, Gram L, Grossart HP, Kessler D and others (2007) Bacteria of the Roseobacter clade show potential for secondary metabolite production. Microb Ecol 54:31-42

Messing J (1983) New M13 vectors for cloning. Methods Enzymol 101:20-78

Mills DK, Fitzgerald K, Litchfield CD, Gillevet PM (2003) A comparison of DNA profiling techniques for monitoring nutrient impact on microbial community composition during bioremediation of petroleum-contaminated soils. J Microbiol Methods 54:57-74

Mills DK, Entry JA, Voss JD, Gillevet PM, Mathee K (2006) An assessment of the hypervariable domains of the 16S rRNA genes for their value in determining microbial community diversity: the paradox of traditional ecological indices. FEMS Microbiol Ecol 57:496-503

Mitchell R, Chet I (1975) Bacterial attack of corals in polluted seawater. Microb Ecol 2:227-233

Muyzer G, de Waal EC, Uitterlinden AG (1993) Profiling of complex microbial populations by denaturing gradient gel electrophoresis analysis of polymerase chain reactionamplified genes coding for 16S rRNA. Appl Environ Microbiol 59:695-700

Muyzer G, Teske A, Wirsen CO, Jannasch HW (1995) Phylogenetic relationship of Thiomicrospira species and their identification in deep-sea hydrothermal vent samples by denaturing gradient gel electrophoresis of 16S rDNA fragments. Arch Microbiol 164:165-172

> Myers JL, Sekar R, Richardson LL (2007) Molecular detection and ecological significance of the cyanobacteria Geitlerinema and Leptolyngbya in black band disease of corals. Appl Environ Microbiol 73:5173-5182

Paul JH, Rose JB, Brown J, Shinn EA, Miller S, Farrah SR (1995) Viral tracer studies indicate contamination of marine waters by sewage disposal practices in Key Largo, Florida. Appl Environ Microbiol 61:2230-2234

Paul JH, Rose JB, Jiang SC, Zhou XT and others (1997) Evidence for groundwater and surface marine water contamination by waste disposal wells in the Florida Keys. Water Res 31:1448-1454

Porter JW, Dustan P, Jaap WC, Patterson KL and others (2001) Patterns of spread of coral disease in the Florida Keys. Hydrobiologia 460:1-24

Ragoonath DN (2005) Heterotrophic capabilities and the molecular identification of a cyanobacterium found in black band disease of coral reefs. MS thesis, Florida International University, Miami, FL

Ramos-Flores T (1983) Lower marine fungus associated with black line disease in star corals (Montastrea annularis). Biol Bull 165:429-435

Rappe MS, Giovannoni SJ (2003) The uncultured microbial majority. Annu Rev Microbiol 57:369-394

Richardson LL (1996) Horizontal and vertical migration patterns of Phormidium corallyticum and Beggiatoa spp. associated with black-band disease of corals. Microb Ecol
32:323-335

Richardson LL (2004) Black band disease. In: Rosenberg E, Loya Y (eds) Coral health and disease. Springer-Verlag, Berlin, p 325-349

Richardson LL, Kuta KG, Schnell S, Carlton RG (1997) Ecology of the black band disease microbial consortium. In: Lessios HA, Macintyre IG (eds) Proc 8th Int Coral Reef Symp. Smithsonian Tropical Research Institute, Balboa, p 597-600

> Rosenberg E, Falkovitz L (2004) The Vibrio shiloi/Oculina patagonica model system of coral bleaching. Annu Rev Microbiol 58:143-159

> Rützler K, Santavy DL (1983) The black band disease of Atlantic reef corals. I. Description of a cyanophyte pathogen. PSZN I: Mar Ecol 4:301-319

Rützler K, Santavy DL, Antonius A (1983) The black band disease of Atlantic reef corals. III. Distribution, ecology and development. PSZN I: Mar Ecol 4:329-358

Sala MM, Balague V, Pedros-Alio C, Massana R and others (2005) Phylogenetic and functional diversity of bacterioplankton during Alexandrium spp. blooms. FEMS Microbiol Ecol 54:257-267

> Schloss PD, Handelsman J (2005) Introducing DOTUR, a computer program for defining operational taxonomic units and estimating species richness. Appl Environ Microbiol 71:1501-1506

Sekar R, Mills DK, Remily ER, Voss JD, Richardson LL (2006) Microbial communities in the surface mucopolysaccharide layer and the black band microbial mat of black banddiseased Siderastrea siderea. Appl Environ Microbiol 72: 5963-5973

Sievert SM, Kiene RP, Schulz-Vogt HN (2007) The sulfur cycle. Oceanography (Wash DC) 20:117-123

Sullivan-Sealey KM (2004) Large-scale ecological impacts of development on tropical islands systems: comparison of developed and undeveloped islands in the central Bahamas. Bull Mar Sci 75:295-320

> Sutherland KP, Porter JW, Torres C (2004) Disease and immunity in Caribbean and Indo-Pacific zooxanthellate corals. Mar Ecol Prog Ser 266:273-302

Viehman S, Mills DK, Meichel GW, Richardson LL (2006) Culture and identification of Desulfovibrio spp. from corals infected by black band disease on Dominican and Florida Keys reefs. Dis Aquat Org 69:119-127

Voss JD (2006) Coral disease dynamics and environmental drivers in the northern Florida Keys and Lee Stocking Island, Bahamas. PhD dissertation, Florida International University, Miami, FL

> Voss JD, Richardson LL (2006a) Coral diseases near Lee Stocking Island, Bahamas: patterns and potential drivers. Dis Aquat Org 69:33-40

> Voss JD, Richardson LL (2006b) Nutrient enrichment enhances black band disease progression in corals. Coral Reefs 25:569-576

> Voss JD, Mills DK, Myers JL, Remily ER, Richardson LL (2007) Black band disease microbial community variation on corals in three regions of the wider Caribbean. Microb Ecol 54:730-739

- Wagner-Dobler I, Biebl H (2006) Environmental biology of the marine Roseobacter lineage. Annu Rev Microbiol 60: 255-280

- Webster NS, Negri AP (2006) Site-specific variation in Antarctic marine biofilms established on artificial surfaces. Environ Microbiol 8:1177-1190

Weil E (2004) Coral reef diseases in the wider Caribbean. In: Rosenberg E, Loya Y (eds) Coral health and disease. Springer-Verlag, Berlin, p 35-68

Submitted: April 11, 2007; Accepted: May 31, 2008

Proofs received from author(s): June 9, 2008 